\section{Local collaborations for physical activity promotion: a network analysis}

\section{Colaborações locais para a promoção da atividade física: uma análise de rede}

Colaboraciones locales para la promoción de la actividad física: un análisis de red
Douglas Roque Andrade 1

Leandro Martin Totaro Garcia 2

Diana C. Parra Perez 3

\begin{abstract}
This study aims to describe a local network for physical activity promotion and identify factors associated to collaboration or partnership ties between its actors. The study was carried out in a district of São Paulo, Brazil. Thirty-two actors responsible for policies, programs, and initiatives to promote physical activity within the district were interviewed from June to December 2012. Interviews included information about the actors' attributes and their relationships with the other actors. Network analysis techniques were used to describe and analyze the structure of the network. Thirty-two actors maintained 179 relationships among themselves (density $=0.18$ ), of which $46 \%$ were reciprocal. Four in 10 relationships did not extend beyond information exchange. Forty-six relationships were classified as collaborations or partnerships (density $=0.09$ ), of which 40\% were concentrated on one actor of the public sector. To perceive institutional structure and bureaucracy as limiting factors to networking has been positively associated with new collaboration or partnership ties $(O R=2.37 ; 95 \% C I: 1.2-5.50)$. Understanding the structure of the network may empower the actors and foster self-management, facilitating the identification and decision, in a collaborative way, in which new relationships may have greater impact in the physical activity promotion within the district.
\end{abstract}

Community Networks; Health Promotion; Social Support

\author{
Correspondence \\ D. R. Andrade \\ Escola de Artes, Ciências e Humanidades, Universidade \\ de São Paulo. \\ Rua Arlindo Béttio 1000, São Paulo, SP 03828-000, Brasil. \\ douglas.andrade@usp.br \\ 1 Escola de Artes, Ciências e Humanidades, Universidade de São \\ Paulo, São Paulo Brasil. \\ 2 Escola Nacional de Saúde Pública Sergio Arouca, Fundação \\ Oswaldo Cruz, Rio de Janeiro, Brasil. \\ 3 Washington University School of Medicine, Saint Louis, U.S.A.
}




\section{Introduction}

Partnerships and cross-sector networks are deemed as important strategies to promote physical activity at an international, national and local level 1,2,3,4,5,6,7. Networks offer multiple advantages, including the sharing of information and knowledge, generation of ideas and innovative solutions, strengthening of capacities, and creation of an interface between knowledge and action, while also promoting closer ties among different sectors of society. In addition, actors are able to meet goals that would be difficult to achieve otherwise, sharing tasks and efforts 6 .

Brazil has interesting examples of networks for physical activity promotion, such as the Agita São Paulo Program and the Brazilian National Health Promotion Policy 3,4. Continental and global networks, such as the Physical Activity Network of the Americas, the European Network for the Promotion of Health-enhancing Physical Activity, the African Physical Activity Network, and the Agita Mundo Network, have been growing in strength. Meanwhile, municipal and local networks, such as the one conformed by the actors involved in the Ciclovía Recreativa in Bogotá 8 , have been existing for decades. They all share the common goal of bringing researchers, decision-makers, program coordinators and other professionals together, to share experiences and optimize policies, programs, and initiatives to promote activity, as well as advocate for the topic in the public health agenda.

Despite the recognition and growth of these networks, studies that assess their features, processes and relationships between the various actors are still rare. Additionally, existing studies have generally examined networks with national or state recognition or reach 9,10,11. Despite the importance of these networks in the advocacy and promotion of physical activity in a large scale, there is also a multitude of local actors that support and expand the possibilities of practices and activities within their communities 8 .

To give visibility and analyze the networks formed by these local actors support them, the community, and researchers to understand how initiatives that promote physical activity are structured at the local level. Moreover, simple applications of the network analysis tools may also support selfmanagement. To understand and inform the relationships maintained between actors within a local network may contribute to their policies, programs and initiatives to promote physical activity by giving them synergy and information to opt for better strategies when establishing partnerships, aiming to meet common goals and reach more effective and sustainable results.

Therefore, this study aims to describe a local network for promotion of physical activity by identifying the factors associated to establishing collaboration or partnership ties.

\section{Method}

\section{Context, population and sample}

The study was geographically limited to Ermelino Matarazzo, a district in the East zone of São Paulo, Brazil. In 2012, when data collection was conducted, the district had an area of $8.95 \mathrm{~km}^{2}$, approximately 114,000 inhabitants, and a population density around 15.420 inhabitants $/ \mathrm{km}^{2}$. Approximately $65 \%$ of the families had a monthly income of up to BRL 3,110.00 (around USD 1,560.00) 12.

In 2012, the district had eight community clubs. Until 2008, these clubs were in deteriorating conditions. Even so, the population used these places to practice physical activity. In 2009, the Sports Division of the Ermelino Matarazzo Regional City Council Office renovated the clubs and trained community leaders to manage them. This caused environmental and management changes that improved the preservation of these facilities. In 2010, the local government of São Paulo selected and hired social organizations to plan and implement physical activity programs in these clubs. The district also has a state park (Tietê Ecological Park), several plazas, a Unified Educational Center with facilities for physical activity, a bicycle lane, and several soccer fields. The region also features a campus of the University of São Paulo (USP), which offers a bachelor's degree in Physical Education and Health.

Within the district, the study was limited to actors who offered physical activity free of charge for the community, excluding amateur soccer teams. Snowball sampling ${ }^{13}$ was used to identify the actors 
within the regional network, since a full list of institutions promoting physical activity in the district was not available. A list was initially prepared containing local actors recognized by the authors as local physical activity promoters. New actors were added to the list as they were mentioned by the people interviewed. Data collection was interrupted when no new actors that corresponded to the study delimitations were mentioned.

\section{Data collection}

Data collection was conducted from June to December 2012, through face-to-face interviews with the highest representative of each institution (e.g., President, Director etc.).

The interview was based on a structured script including 27 questions, based on the questionnaires used by Brownson et al. ${ }^{9}$ and Parra et al. ${ }^{10}$. Questions included the respondent's demographic and professional information; identification of actors who promote physical activity within the district, through spontaneous mention; description of the relationship maintained with the mentioned actors, which included how often they speak, the level of relationship, and the actors' importance for the network; and barriers and challenges for networking.

Before data collection, the script was tested with four people outside the assessed network to confirm clarity of the questions asked to the respondents, time and procedures of interview, and whether all the information required to the project would be collected and processed adequately. Additionally, six researchers evaluated the script and corrected it whenever necessary.

Two trained interviewers conducted all interviews. Double entry and consistency check were used to minimize errors in the database.

\section{Variables and attributes}

Details about the questions and responses used in the paper are reported in Supplementary Material S1 (http://cadernos.ensp.fiocruz.br/csp/public_site/arquivo/csp-1275-17-supplementary-materialing_4131.pdf). Actors were classified in four categories: open streets, community clubs, social organizations, and public sector. The quantity of years working in the institution and with physical activity promotion was obtained from all respondents.

For the attributes of actors and relationships and the network structure, we assessed: (a) level of relationship: unlinked (do not work together), communication (only share information), cooperation (informally work together towards common goals), collaboration (formally work together towards common goals), or partnership (formally work together on several projects towards common goals); (b) contact frequency: daily, weekly, monthly, quarterly, biannually, annually, or never; (c) degree centrality: amount of relationships maintained by the actor, divided into indegree (citations the actor has received) and outdegree (citations the actor has made) 14; (d) betweenness centrality: normalized amount (i.e., varying from 0 to 1 ) of shortest paths connecting all actors to all others that pass through the actor under assessment. Actors with high betweenness centrality function as bridges between other actors in the network, assuming that shortest paths are the most desirable ones 14; (e) network density: ratio between the amount of existing relationships within the network and the maximum possible number of ties (i.e., if all actors were interconnected) 14; (f) density of reciprocal relationships: ratio between the amount of reciprocal relationships and the total number of ties within the network 14; (g) maximum geodesic distance: highest geodesic distance (i.e., shortest distance between two actors, measured by the number of ties to connect them) of the network 14; (h) mean geodesic distance: arithmetic mean of all geodesic distances; 14 ; (i) main component size: number of actors in the largest set of connected actors 14 .

Finally, certain attributes were only used for the predictive modeling: (a) barriers to networking reported by actors: lack of time, institutional structure/bureaucracy, incompatible strategies between actors, and benefits not outweigh the cost of collaboration; (b) geometrically weighted dyadwise shared partner (GWDSP): structural attribute that captures the tendency of pairs of actors to have identical relationships with others within the network 15 . 


\section{Data analysis}

For the descriptive analyses, mean, standard deviation (SD), absolute and relative frequencies, network graphs, and charts (columns, pie and probability density) were used.

We used exponential random graph models (ERGM) to identify factors associated with the formation of collaboration or partnership relationships between members of the network 15, through the following steps: (1) we transformed a citation (directed) network into an institutional tie (undirected) network (i.e., directionality between relationships were removed). To define the relationship level of nonreciprocal ties, we used imputation by reconstruction 16. Whenever the relationships were reciprocal, we considered the average level; (2) only collaboration/partnership ties were kept, as they reflect formal ties between institutions and tend to be more consistent and stablished types of relationship; (3) bivariate analyses (i.e., simple ERGM) were conducted to select the attributes of actors, relationships, and structure associated with collaborative or partnership relationships (for the list of attributes tested see Supplementary Material S2. http://cadernos.ensp.fiocruz.br/csp/public_site/ arquivo/csp-1275-17-supplementary-material-ing_4131.pdf) to use in the models. We adopted a significance level of 10\%; (4) three models were built: (a) null, as reference; (b) actors' attributes (type and barriers for networking); (c) actors' and structural (GWDSP) attributes. Actors' attributes from the previous model were kept and structural attributes were included until model fitness started decreasing (see next step). Due to the results from the bivariate analyses, none of the attributes of the edges were selected. Other structural attributes besides GWDSP were considered during the modelling process (see Supplementary Material S2. http://cadernos.ensp.fiocruz.br/csp/public_site/arquivo/ csp-1275-17-supplementary-material-ing_4131.pdf), but were not kept in the final model because there was no evidence of association or improvement in the model fitness; (5) model fitness was assessed using deviance scores and Akaike and Bayesian information criteria. The lower the values, the better fitted the models. Also, to assess the model fitness, the observed network was compared to 1,000 networks simulated from the models, regarding the amount of relationships and triangles (i.e., three actors interconnected), distribution of degree centrality, minimum geodesic distance, neighbors shared by connected actors, and neighbors shared by pairs of actors (whether they are connected or not) 15 .

ERGM results include odds ratio (OR) and 95\% confidence interval (95\%CI). Analyses and illustrations were made using NodeXL Excel Template 2014 (https://www.smrfoundation.org/nodexl/ installation/), and R version 3.1.2 (The R Foundation for Statistical Computing, Vienna, Austria; http://www.r-project.org), with the network, sna, statnet and ggplot2 packages.

\section{Ethical aspects}

The research was approved by the Human Research Ethics Committee of the School of Arts, Sciences and Humanities of the USP (protocol number 22618). All participants signed an informed consent term.

\section{Results}

Thirty-two actors were interviewed: ten from open streets, nine from community clubs, nine from social organizations, and four from the public sector. On average, respondents worked 12 years $(\mathrm{SD}=10)$ for the institution, and 15 years $(\mathrm{SD}=9)$ promoting physical activity.

The 32 actors maintained 179 relationships among themselves, of which $46 \%$ were reciprocal. Despite the low density (0.18), all actors were part of the same component and any actor could reach any other within the network requiring only, on average, one intermediator, but no more than three (mean geodesic distance $=2$, maximum geodesic distance $=4$ ).

Subnetworks formed by actors of the same type had different connectivity patterns. The community club subnetwork had $80 \%$ of reciprocal relationships and a density of 0.73 , as the open streets subnetwork had no reciprocal relationship and a density of 0.01 . The social organization subnetwork 
had $17 \%$ of reciprocal relationships and a density of 0.17 . Meanwhile, the public-sector actors had $57 \%$ reciprocal relationships and a density of 0.58 .

Figure 1 depicts the entire citation network, including all aforementioned relationships. Approximately one third of the actors within the network was not mentioned at all or only one time, as the another one third was mentioned 10 times or more (indegree). Twenty of the 32 actors recognized up to five actors within the district (outdegree). Actors were heterogeneous with regard to betweenness centrality but concentrating lower values (Figure 2).

Four in every 10 relationships in the network did not extend beyond communication, as $13 \%$ of them were reported as collaboration (formally working together towards common goals) and $22 \%$ as partnerships (formally working together on several projects towards common goals). In $25 \%$ of the relationships, communication would happen once a year or never. On the other hand, $43 \%$ of the contacts ranged from daily to monthly (more details in Supplementary Material S1. http://cadernos. ensp.fiocruz.br/csp/public_site/arquivo/csp-1275-17-supplementary-material-ing_4131.pdf).

Figure 3 represents relationships of collaboration and partnership within the network. There were 46 of them, with a density (0.09) - half the density observed in the entire network - and four actors disconnected from the main component. The maximum geodesic distance was six, with a mean of three. Fourteen (44\%) of the 32 actors had none or one collaboration or partnership tie. One actor from the public sector concentrated $40 \%$ of the collaboration and partnership relationships of the net-

\section{Figure 1}

Network for physical activity promotion. District of Ermelino Matarazzo, São Paulo, Brazil, 2012.

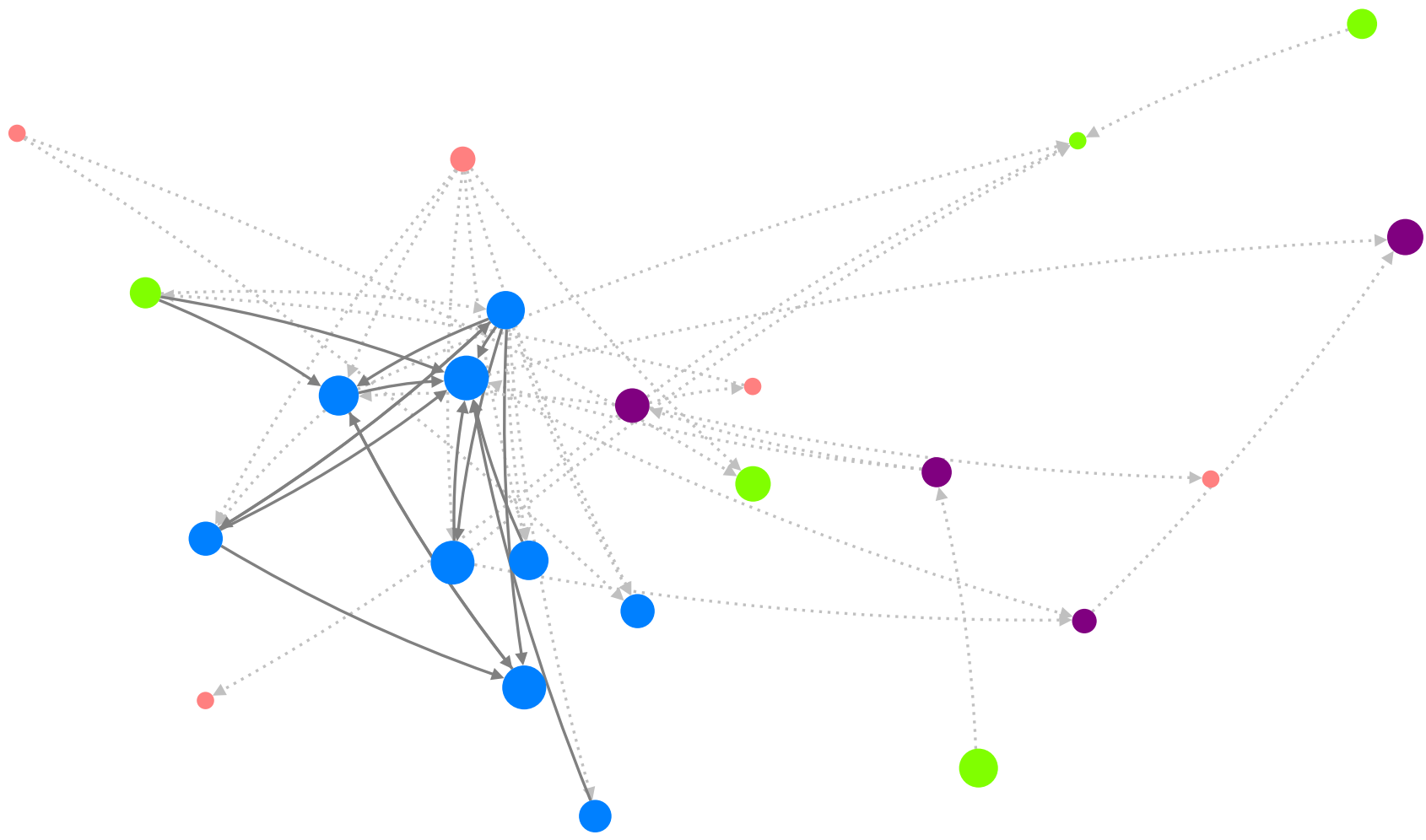

Actors (circles): pink = open streets; blue = community clubs; green = social organizations; purple = public sector. The bigger the circle, the bigger the ratio of reciprocal relationships. Relationships (lines): continuous = reciprocal; dotted = non-reciprocal. The graph includes all relationships cited by each institution and direction of the line shows who mentioned $\rightarrow$ who was mentioned. 


\section{Figure 2}

Distribution of indegree, outdegree and betweenness centralities in the network for physical activity promotion (considering all relationships cited by each institution). District of Ermelino Matarazzo, São Paulo, Brazil, 2012.

2a) Indegree

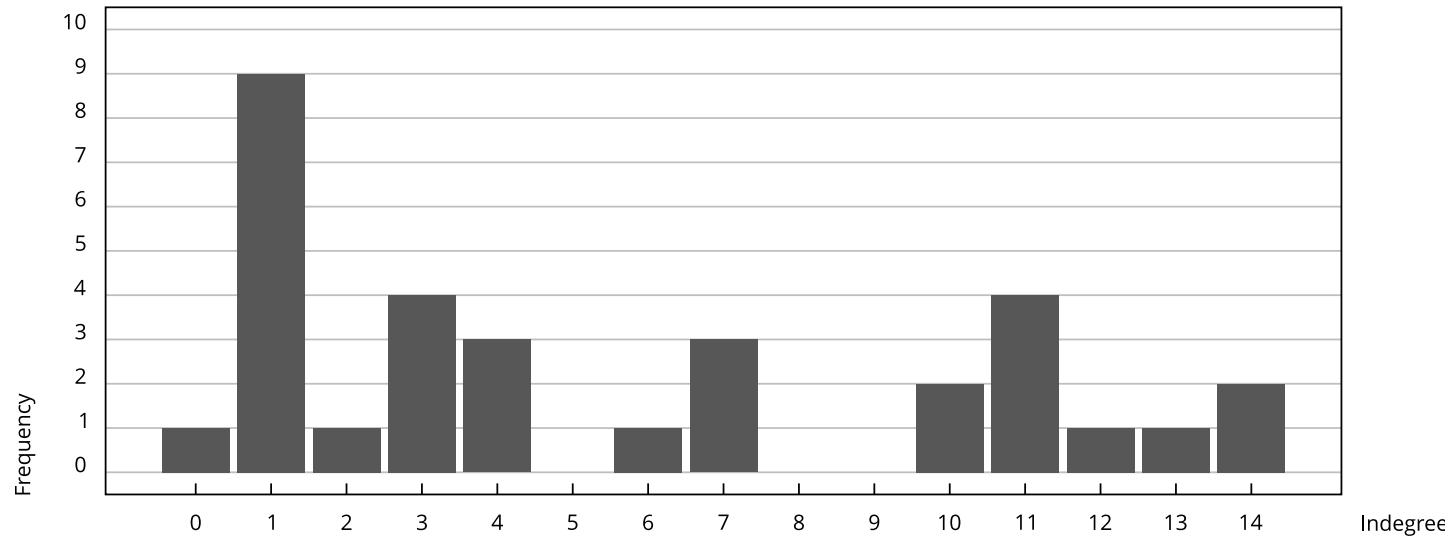

2b) Outdegree

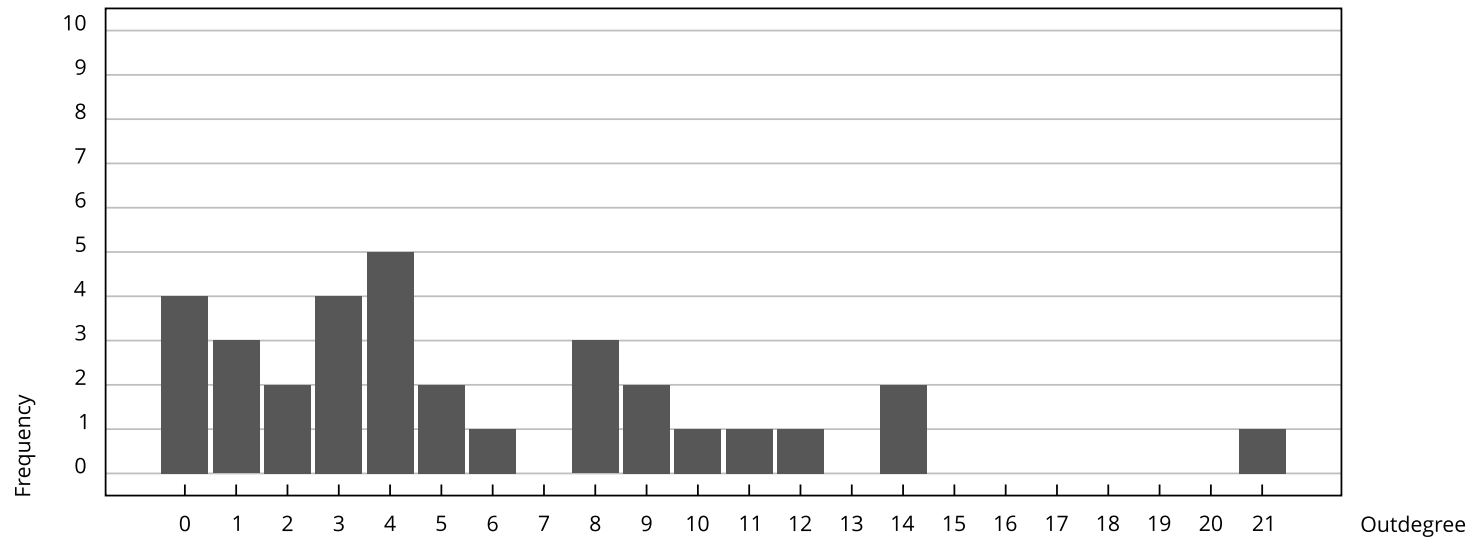

2c) Betweenneess

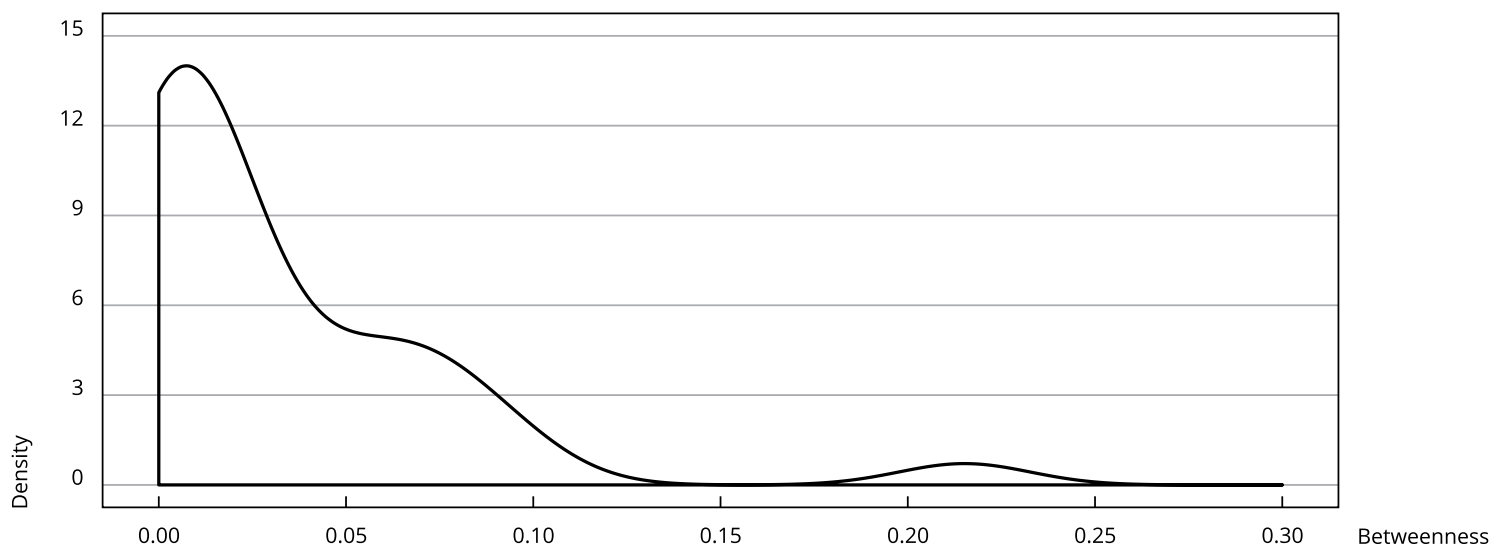




\section{Figure 3}

Collaboration or partnership relationships in the network for physical activity promotion. District of Ermelino Matarazzo, São Paulo, Brazil, 2012.

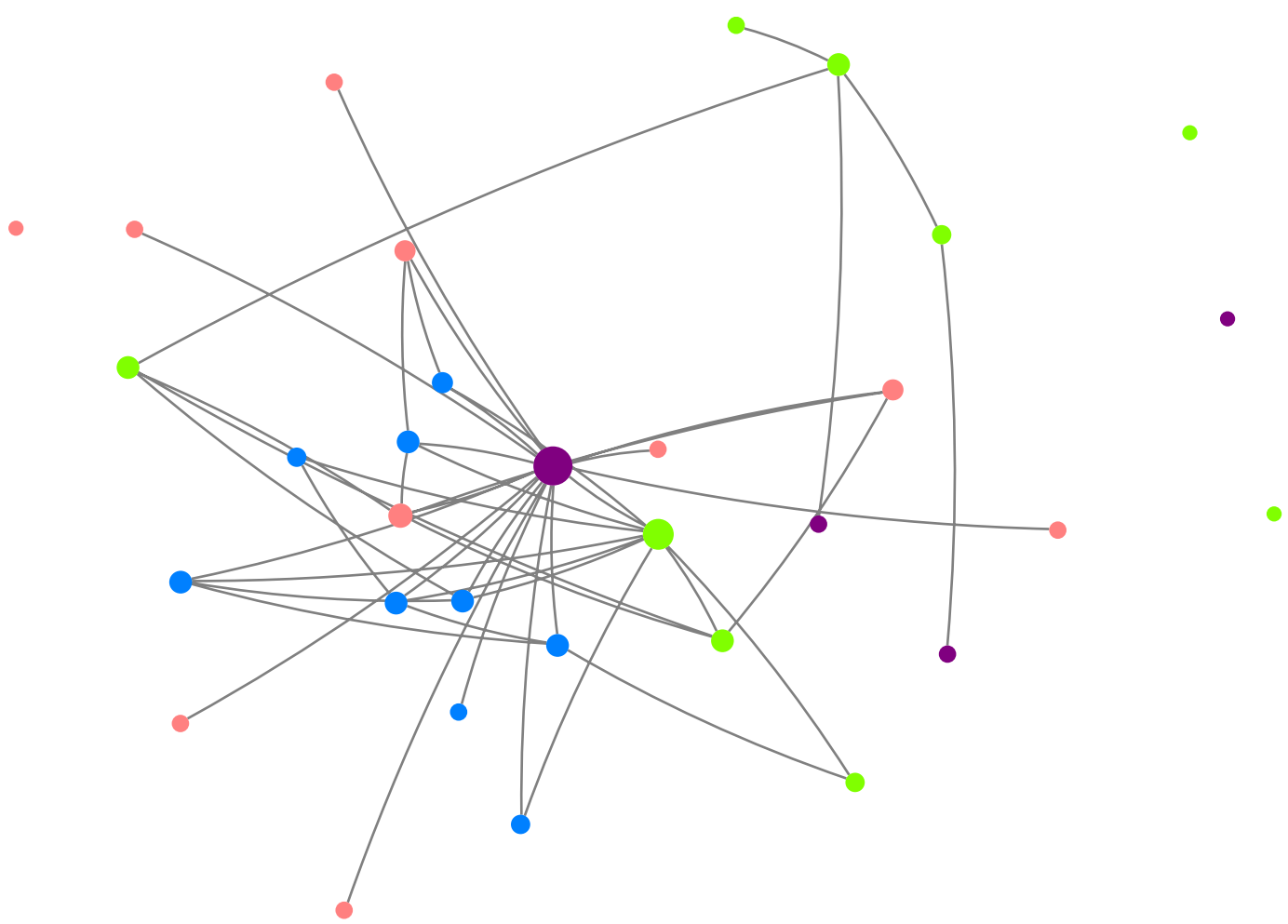

Actors (circles): pink = open streets; blue = community clubs; green = social organizations; purple = public sector. The bigger the circle, the higher its degree.

work (the largest purple circle in Figure 3). As in the entire network, there is a concentration of actors with low betweenness centrality, but a heterogeneous distribution of values (Figure 4). Sixty-five per cent of the relationships involved contact frequencies ranging from daily to monthly.

As in the full network, subnetworks formed by actors of the same type had different connectivity patterns. The community club subnetwork had a density of 0.11 , and $4 / 9$ of the actors were disconnected from the rest. As for the open streets subnetwork, density was 0.02 and 8/10 of the actors were not connected to the main component. The social organization network had a density of 0.17 and 2/9 of actors disconnected. Within the public sector, all actors were disconnected from each other, which resulted in zero density of collaboration and partnership ties.

Regarding the predictive models, when considering just the actors' attributes, those in the public sector had higher odds of generating collaboration or partnership relationships than all other actors. This difference did not remain when the structural attribute GWDSP was included. GWDSP showed a positive association with the likelihood of forming new relationships of collaboration or partnership (OR =1.22; 95\%CI: 1.18-1.26). Unlike the expected, perceiving institutional structure/ bureaucracy as a limiting factor to networking was positively associated to forming new collaboration or partnership ties, even when structural attributes where added to the model $(\mathrm{OR}=2.37 ; 95 \% \mathrm{CI}$ : 1.02-5.50) (Table 1).

The model with the actors' and structural attributes showed the best fitness to the data (see Table 1 for deviance scores and Akaike and Bayesian information criteria; details about the comparison 


\section{Figure 4}

Distribution of degree and betweenness centralities in the network of collaboration and partnership among actors promoting physical activity. District of Ermelino Matarazzo, São Paulo, Brazil, 2012.

4a) Degree

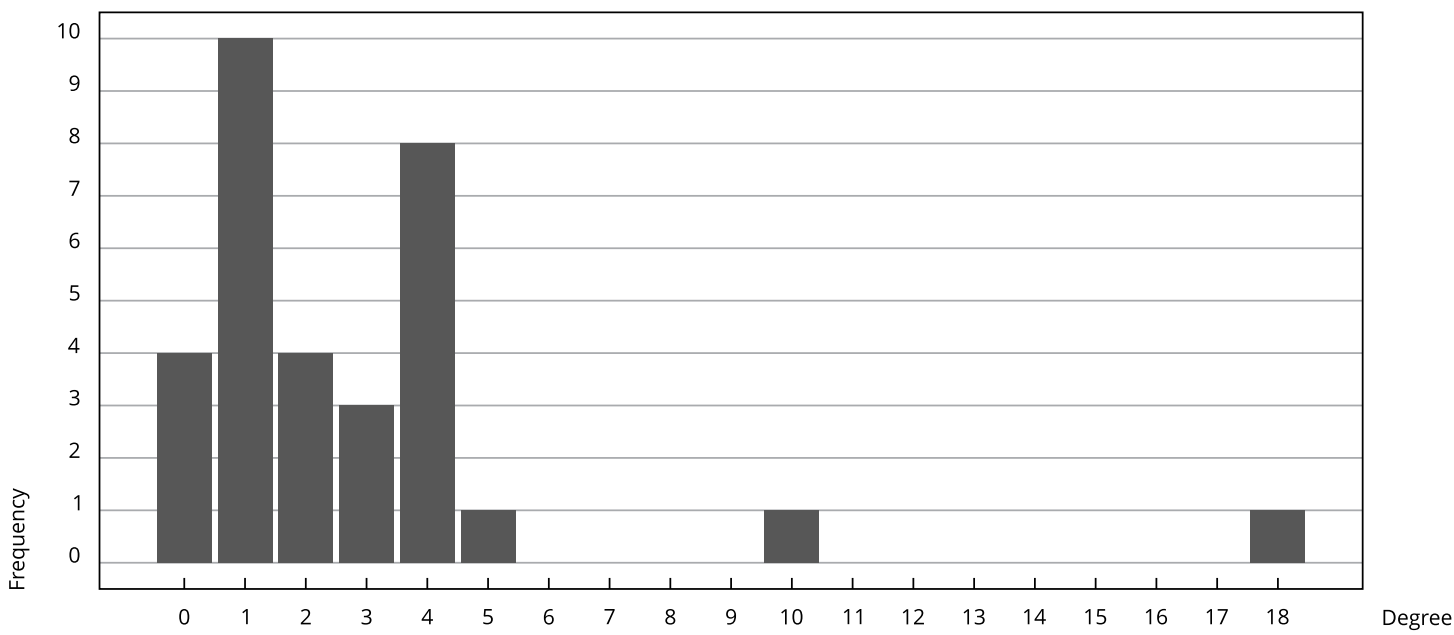

4b) Betweenness

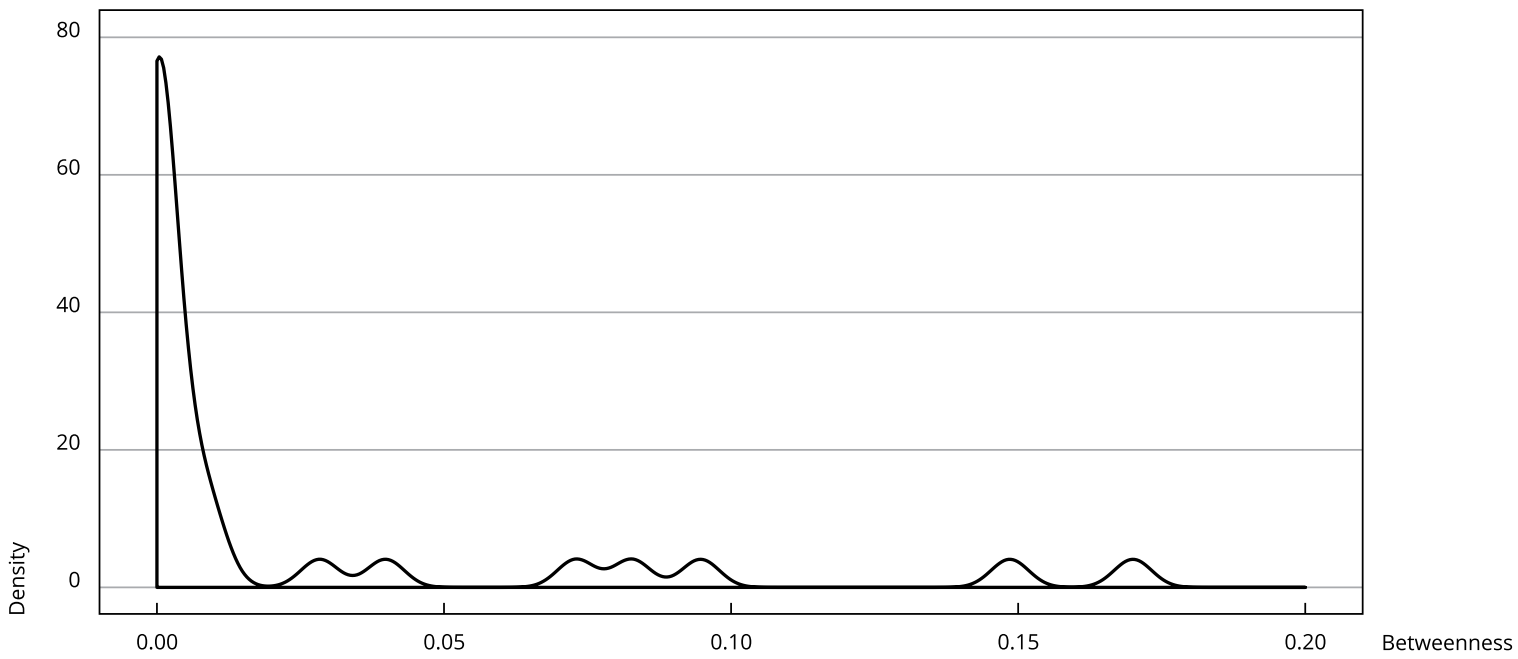

between the observed and simulated networks are available in the Supplementary Material S3. http:// cadernos.ensp.fiocruz.br/csp/public_site/arquivo/csp-1275-17-supplementary-material-ing_4131. pdf). Other structural attributes were tested in the multivariable model (see Supplementary Material S2. http://cadernos.ensp.fiocruz.br/csp/public_site/arquivo/csp-1275-17-supplementary-materialing_4131.pdf), but showed no significant association, significant adjustment of the effect size of other variables in the model nor improvement of the model fitness. Therefore, they were excluded from the final model for parsimony. 
Table 1

Predictive models of new collaboration or partnership relationships between two actors in the network for physical activity promotion. District of Ermelino Matarazzo, São Paulo, Brazil, 2012.

\begin{tabular}{|c|c|c|c|c|c|c|}
\hline \multirow[t]{2}{*}{ Attributes } & \multicolumn{2}{|c|}{ Null model } & \multicolumn{2}{|c|}{ Model with actors' attributes } & \multicolumn{2}{|c|}{$\begin{array}{c}\text { Model with actors' and } \\
\text { structural }\end{array}$} \\
\hline & OR & $95 \% \mathrm{Cl}$ & OR & $95 \% \mathrm{Cl}$ & OR & $95 \% \mathrm{Cl}$ \\
\hline Relationships & 0.11 & $0.08-0.15$ & 0.01 & $0.00-0.08$ & 0.00 & $0.00-0.01$ \\
\hline \multicolumn{7}{|l|}{ Type of actor } \\
\hline Community clubs & & & 0.41 & $0.19-0.87$ & 0.99 & $0.74-1.31$ \\
\hline Open streets & & & 0.27 & $0.12-0.60$ & 0.73 & $0.40-1.34$ \\
\hline Social organizations & & & 0.42 & $0.20-0.42$ & 0.96 & $0.71-1.31$ \\
\hline Public sector & & & Ref. & & Ref. & \\
\hline \multicolumn{7}{|l|}{ Barriers to networking } \\
\hline Lack of time & & & 1.69 & $0.99-2.90$ & 1.29 & $0.79-2.11$ \\
\hline Institutional structure/bureaucracy & & & 2.44 & $1.07-5.53$ & 2.37 & $1.02-5.50$ \\
\hline Incompatible goals and strategies & & & 1.81 & $0.99-3.31$ & 1.48 & $0.84-2.60$ \\
\hline Benefits do not outweigh the costs & & & 2.53 & $1.42-4.53$ & 1.66 & $0.96-2.88$ \\
\hline GWDSP & & & & & 1.22 & $1.18-1.26$ \\
\hline \multicolumn{7}{|l|}{ Model adjustment } \\
\hline Deviance & \multicolumn{2}{|c|}{644.6} & \multicolumn{2}{|c|}{585.8} & \multicolumn{2}{|c|}{226.1} \\
\hline AIC & \multicolumn{2}{|c|}{646.6} & \multicolumn{2}{|c|}{601.8} & \multicolumn{2}{|c|}{244.1} \\
\hline $\mathrm{BIC}$ & \multicolumn{2}{|c|}{650.8} & \multicolumn{2}{|c|}{635.0} & \multicolumn{2}{|c|}{281.4} \\
\hline
\end{tabular}

95\% CI: 95\% confidence interval; AIC: Akaike information criterion; BIC: Bayesian information criterion; GWDSP: geometrically weighted dyadwise shared partner; OR: odds ratio; Ref.: reference.

Note: in bold - statistically significant association.

\section{Discussion}

The aims of this study were to describe a local network for physical activity promotion and to identify the factors associated to collaborative or partnership work. We interviewed 32 actors from Ermelino Matarazzo, a district of São Paulo, Brazil. These actors had established 179 relationships among themselves, $46 \%$ of which were reciprocal. It is a low-density, decentralized network. Around $40 \%$ of these relationships did not extend beyond information exchange, and $20 \%$ were collaboration or partnership relationships. While investigating the network of collaboration or partnership, an even lower density was observed, although high centralization (one actor from the public sector concentrated $40 \%$ of the existing relationships). A pre-transitivity status was also observed, in wich the probability of formation of triangles (i.e., three actors interconnected) was higher than expected in a random network. Unexpectedly, perceiving institutional structure and bureaucracy as a barrier to networking seemed to be positively associated to starting new collaboration or partnership relationships.

Despite the low density, the low betweenness centrality by most actors, and the asymmetrical recognition of relationships (only $46 \%$ of the relationships were reciprocal), any actor could always reach another within the network, usually requiring no more than one intermediator. While there is potential to improve and strengthen networking in the community, the transformation of this potential must not actually be based simply on the densification of relationships. On the contrary, the capacity of all actors to access the resources available in the network (information, material, people, etc.) must be based on a different organization logic. One of the greatest advantages of a network organization is the bridge offered by local relationships to overall resources, since actors can perform different structural roles within the network, avoiding intensive efforts from each actor to maintain many relationships 17,18 . 
A similar scenario was observed in the analysis focused on collaboration or partnership relationships, with two aggravating factors: four actors were disconnected from the main component of the network, and the mean and maximum geodesic distance were 50\% higher than the ones observed in the entire network. The density of collaboration and partnership relationships was considerably lower when compared to the Colombian (0.44) 10 and the Brazilian (0.31) 9 networks for physical activity promotion. However, these were nationwide networks and the Brazilian one had several research institutions. A similar investigation with a statewide network (Hawaii, USA) observed a density of collaboration and partnership similar to our research (0.11) 11. It is not clear whether density of institutional collaborations truly scales with the level of observation (i.e., local, citywide, statewide, nationwide, international). Results from further networks for physical activity promotion (and perhaps even other health-related behavior) could confirm whether this is a common, consistent feature and, if so, its causes.

The collaboration and partnership network could be more robust and collaborative by establishing relationships with the four actors that are disconnected. It could also include strategic relationships between key actors, reducing the number of required intermediators between any two actors. With that in mind, to understand how a network is organized may be a great way to empower and promote self-management among actors 18,19. By sharing the same network vision, actors would be able to identify and decide, in a collaborative way, to form new relationships. In turn, these new ties may have a positive impact on the overall physical activity promotion in the district, beyond strengthening the initiatives of separate institutions 6,18,19. Better knowledge about the network structure may facilitate how each actor identifies and accesses resources (information, funding, equipment, places, technical capacity, etc.) available from other local institutions, and at same time how to share and potentialize its own resources. For instance, when activities and programs offered by each actor are disseminated through the network and then more effectively to the community, people living in the district gain access to more opportunities to be physically active.

The pre-transitive status of the network indicates that the likelihood of two actors who had a relationship with a common third actor starting a collaboration or partnership was higher than the expected in a random network 15 . This result suggests that something other than the actors' role in the network has been preventing such triangles from being formed. At the same time, it indicates a potential for stronger joint initiatives.

Our analysis shows that one actor from the public sector concentrated $40 \%$ of all collaboration and partnership relationships in the network, which is similar to the observed in the Colombian and Brazilian networks 10, possibly because governmental institutions are responsible for regulating, articulating, and financing actions across governmental and non-governmental sectors. In any case, this concentration is a concern due to recurrent instabilities and changes in the political scenario, reducing the robustness of the network. Therefore, we believe that this public-sector actor should use its leadership to contribute further for the identification, creation, and implementation of strategies to bring other actors together. This would expand relationships of collaboration and partnership without creating dependency from other actors to the public sector. In fact, this is a recognized strategy to improve health results 18,20,21. Regular meetings involving all actors, aiming to share experiences and seek solutions to common management problems, could be a strategy that would contribute to expand the possibilities for participation 20 and to the emergence and recognition of other leaderships within the community.

The perception of institutional structure and bureaucracy as a limiting factor was positively associated with the establishment of collaboration or partnership relationships, which was also observed in the Colombian and Brazilian networks 10. Supplementary studies (e.g., in-depth qualitative interviews) are necessary to understand the reason and meaning of these findings. One hypothesis is that actors that develop these types of relationships have identified the problem and its impact in their work processes, but also attempted to overcome this barrier, which rendered it more noticeable. A strategy for the actors to establish networks would be to understand the bureaucracy and how to allow joint activity. At the same time, it seems that reviewing institutional bureaucratic processes is necessary to facilitate such partnerships.

Certain limitations of this study must be considered. Firstly, snowball sampling may bias the actors mentioned and interviewed, depending where the process starts. We attempted to avoid that 
by preparing an initial list of actors across several sectors. Secondly, the respondent could possibly be unaware of all the relationships maintained by his/her institution, or be completely informed on their levels. Thirdly, respondents could have different interpretations regarding networking and relationship levels, which we attempted to minimize offering conceptual anchors during the interview. Fourthly, there are more actors involved in the physical activity promotion within the district than the ones included in the study. For instance, hundreds of amateur soccer teams (which, by itself, constitutes a network), as well as private gyms and jogging clubs. Finally, we did not investigate how and why the relationships were formed (e.g., shared interests or needs). Future studies investigating the formation of networks for physical activity promotion would benefit from including these topics into the research.

To our knowledge, this study is one of the few analyzing the structure and characteristics of a local network that aims to promote physical activity. Comparing networks with different territorial coverage and reach allows to understand similarities and idiosyncrasies across all levels, enabling optimal usage of capacities and structures to promote physical activity. However, the most immediate and important application of the study is the use of its results by the actors themselves, allowing them to visualize, understand and intervene in the network, aiming to find ways to make it denser and collaborative. In that sense, after this study, we have been meeting with the most important actors - as identified by the descriptive analyses - to engage them as leaders of this movement. One result was the first Meeting of the Ermelino Matarazzo Physical Activity Network (RAFEM) held in May 2014, with all actors interviewed, as well as other actors from the district.

Finally, we believe that the most basic and descriptive tools for network analysis are, in fact, useful and feasible for implementation in the daily activities of managers and practitioners involved in the physical activity promotion. For instance, mapping and integration of facilities and initiatives, and cooperation within and outside the sector and the territory - elements of the Brazilian National Health Promotion Policy 2 - could benefit from this incorporation. However, there are still several challenges preventing the implementation of recommended networking practices, such as lack of political and technical preparation of managers and practitioners to work as a network 22 . Considering that there is a mismatch of interests between practitioners and researchers 23 , it would be desirable to promote closer ties between researchers and local leaderships. Changing how we prepare for and deal with network management could improve quality, robustness and sustainability of policies, programs, and initiatives, and, as a consequence, increase the community level of physical activity.

\section{Contributors}

D. R. Andrade conceived the project, interpreted the results and drafted the article. L. M. T. Garcia analyzed the data, interpreted the results and drafted the article. D. C. P. Perez interpreted the results and critically reviewed the article. All the authors approved the final version and is responsible for all aspects of the manuscript.

\section{References}

1. Bull FC, Bellew B, Schoppe S, Bauman AE. Developments in national physical activity policy: an international review and recommendations towards better practice. J Sci Med Sport 2004; 7(1 Suppl):93-104.

2. Ministério da Saúde. Portaria MS/GM no 2.446, de 11 de novembro de 2014. Redefinição da Política Nacional de Promoção da Saúde (PNPS). Diário Oficial da União 2014; 13 nov.

3. Knuth AG, Malta DC, Cruz DK, Castro AM, Fagundes J, Sardinha LM, et al. Description of the countrywide physical activity network coordinated by the Brazilian Ministry of Health: 2005-2008. J Phys Act Health 2010; 7 Suppl 2:S253-8. 
4. Malta DC, Silva M, Albuquerque G, Amorim R, Rodrigues G, Silva T, et al. Política Nacional de Promoção da Saúde: descrição da implementação do eixo atividade física e práticas corporais 2006-2014. Rev Bras Ativ Fís Saúde 2014; 19:286-99.

5. World Health Organization. Global strategy on diet, physical activity and health. Geneva: World Health Organization; 2004.

6. Organização Pan-Americana da Saúde. Gestão de redes na OPAS/OMS Brasil: conceitos, práticas e lições aprendidas. Brasília: Organização Pan-Americana da Saúde; 2008.

7. Heath GW, Parra DC, Sarmiento OL, Andersen LB, Owen N, Goenka S, et al. Evidencebased intervention in physical activity: lessons from around the world. Lancet 2012; 380: 272-81.

8. Meisel JD, Sarmiento OL, Montes F, Martinez EO, Lemoine PD, Valdivia JA, et al. Network analysis of Bogota's Ciclovia Recreativa, a self-organized multisectorial community program to promote physical activity in a middleincome country. Am J Health Promot 2014; 28:e127-36.

9. Brownson RC, Parra DC, Dauti M, Harris JK, Hallal PC, Hoehner C, et al. Assembling the puzzle for promoting physical activity in Brazil: a social network analysis. J Phys Act Health 2010; 7 Suppl 2:S242-52.

10. Parra DC, Dauti M, Harris JK, Reyes L, Malta DC, Brownson RC, et al. How does network structure affect partnerships for promoting physical activity? Evidence from Brazil and Colombia. Soc Sci Med 2011; 73:1365-70.

11. Buchthal OV, Taniguchi N, Iskandar L, Maddock J. Assessing state-level active living promotion using network analysis. J Phys Act Health 2013; 10:19-32.

12. Secretaria Municipal de Desenvolvimento Urbano. Infocidade. http://infocidade.prefeitura. sp.gov.br/ (accessed on 06/Aug/2016).
13. Goodman LA. Snowball sampling. Ann Math Stat $1961 ; 32: 148-70$.

14. Newman MEJ. Networks: an introduction. Oxford: Oxford University Press; 2010.

15. Harris JK. An introduction to exponential random graph modeling. Thousand Oaks: Sage; 2014.

16. Huisman M. Imputation of missing network data: some simple procedures. J Soc Struct 2009; 10:1-29.

17. Easley D, Kleinberg J. Strong and weak ties. In: Easley D, Kleinberg J, editors. Networks, crowds, and markets: reasoning about a highly connected world. New York: Cambridge University Press; 2010. p. 47-84.

18. Varda DM. Data-driven management strategies in public health collaboratives. J Public Health Manag Pract 2011; 17:122-32.

19. Frahsa A, Rutten A, Roeger U, Abu-Omar K, Schow D. Enabling the powerful? Participatory action research with local policymakers and professionals for physical activity promotion with women in difficult life situations. Health Promot Int 2014; 29:171-84.

20. Mendes R, Bógus CM, Westphal MF, Fernandez JCA. Promoção da saúde e redes de lideranças. Physis (Rio J.) 2013; 23:209-26.

21. Retrum JH, Chapman CL, Varda DM. Implications of network structure on public health collaboratives. Health Educ Behav 2013; 40(1 Suppl):13S-23S.

22. Azevedo E, Pelicioni MCF, Westphal MF. Práticas intersetoriais nas políticas públicas de promoção de saúde. Physis (Rio J.) 2012; 22:1333-56.

23. Reis RS, Kelly CM, Parra DC, Barros M, Gomes G, Malta D, et al. Developing a research agenda for promoting physical activity in Brazil through environmental and policy change. Rev Panam Salud Pública 2012; 32:93-100. 


\section{Resumo}

Este estudo teve como objetivo descrever uma rede local de promoção da atividade física e identificar os fatores associados ao trabalho em colaboração ou parceria entre os seus atores. O trabalho foi realizado em Ermelino Matarazzo, distrito do Município de São Paulo, Brasil. Foram entrevistados, no período de junho a dezembro de 2012, 32 atores responsáveis por ações, programas ou politicas de promoção da atividade física no distrito. A entrevista continha informações sobre as características dos atores e de suas relações com os demais atores. A estrutura das relações foi explorada por meio de técnicas de análise de redes. Os 32 atores mantinham entre si 179 relações (densidade = 0,18), sendo $46 \%$ recíprocas. Quatro em cada dez relações não iam além da troca de informações. Quarenta e seis relações foram de colaboração ou parceria (densidade =0,09), das quais 40\% se concentraram em um único ator do setor público. A percepção de que a estrutura e a burocracia institucional são fatores limitantes para realizar parcerias esteve positivamente associada ao estabelecimento de uma relação de colaboração ou parceria $(O R=2,37$; IC95\%: 1,02-5,50). Compreender a estrutura da rede pode ser uma poderosa forma de fortalecer os atores e a autogestão da rede, facilitando a identificação e a tomada de decisão, de forma colaborativa, sobre quais novas relações podem ter maior impacto na promoção da atividade física dentro do distrito.

Redes Comunitárias; Promoção da Saúde; Apoio Social

\section{Resumen}

El objetivo de este estudio fue describir una red local de promoción de la actividad física e identificar los factores asociados al trabajo en colaboración o asociación entre sus actores. El trabajo se realizó en Ermelino Matarazzo, distrito del municipio de São Paulo, Brasil. Se entrevistaron, durante el período de junio a diciembre de 2012, a 32 actores responsables de acciones, programas o politicas de promoción de la actividad física en ese distrito. La entrevista contenía información sobre las características de los actores y de sus relaciones con los demás actores. La estructura de las relaciones se examinó mediante técnicas de análisis de redes. Los 32 actores mantenian entre si 179 relaciones (densidad $=0,18$ ), siendo $46 \%$ recíprocas. Cuatro de cada diez relaciones no iban más allá del intercambio de información. Cuarenta y seis relaciones fueron de colaboración o asociación (densidad = 0,09), de las cuales un 40\% se concentraron en un único actor del sector público. La percepción de que la estructura y la burocracia institucional son factores limitadores para establecer asociaciones estuvo positivamente asociada al establecimiento de una relación de colaboración o asociación $(O R=2,37$; IC95\%: 1,02-5,50). Comprender la estructura de la red puede ser una poderosa forma de fortalecer a los actores y la autogestión de la red, facilitando la identificación y la toma de decisiones, de forma colaborativa, sobre qué nuevas relaciones pueden tener un mayor impacto en la promoción de la actividad física dentro del distrito.

Redes Comunitarias; Promoción de la Salud; Apoyo Social
Submitted on $26 / \mathrm{Jul} / 2017$

Final version ressubmitted on $28 / \mathrm{Feb} / 2018$

Approved on 18/May/2018 